\title{
28 Research Soure \\ Production and Escalation of L-Lysine via Bacterial Fermentation Utilizing Streptococcus Sp
}

\section{University of Education \\ Mehreen Sarfraz \\ University of Education \\ Zohaib Ahmad \\ University of Gujrat \\ Nuzhat Munawar \\ University of Education \\ Zeeshan Rehman \\ University of Education \\ Saira Ahmad \\ University of the Punjab}

Shanzay Saleem ( $\sim$ shanzay36@live.com )

\section{Research Article}

Keywords: Lysine, Fermentation, Bacteria, Streptococcus sp., Optimization, Media

Posted Date: November 15th, 2021

DOI: https://doi.org/10.21203/rs.3.rs-1038970/v1

License: (c) (i) This work is licensed under a Creative Commons Attribution 4.0 International License.

Read Full License 


\section{Abstract}

\section{Background and Aims}

The importance of L-lysine as an essential amino acid in the nutrition of human beings has made it desirable supplement of the diet in recent years. It can be produced in different ways among them fermentation is the most economical and practical means of producing lysine. In this method low temperature, low pressure and low-cost carbon sources are used and a biological form of lysine (L-lysine) is produced.

\section{Methods}

In the present study, the production of L-lysine was achieved through fermentation developed from locally isolated bacterial strains. In total, twenty-nine (29) bacterial strains were isolated and tested using paper chromatographic technique. Six different parameters for optimization were scrutinized for improved bacterial growth and significant yield of lysine was obtained using selected strains.

Key Results

For Streptococcus sp. molasses media with vitamins (w) formed $24.4 \mathrm{~g} / \mathrm{L}, 40^{\circ} \mathrm{C}$ generated $24.4 \mathrm{~g} / \mathrm{L}$, addition of $1 \mathrm{mM}$ solution of metal ion ( $\mathrm{Mg}$ ) yielded $20.4 \mathrm{~g} / \mathrm{L}, \mathrm{pH} 6.5$ delivered $6 \mathrm{~g} / \mathrm{L}$, fermentation period of 96 hours engendered $24.4 \mathrm{~g} / \mathrm{L}$, and $0.3 \mathrm{~mL}$ of inoculum results in $9.2 \mathrm{~g} / \mathrm{L}$ of lysine.

\section{Conclusions}

Laboratory scale production of L-lysine was carried out using $1 \mathrm{~L}$ Erlenmeyer flask. For Streptococcus sp. $23.4 \mathrm{~g} / \mathrm{L}$ of lysine was produced after optimized conditions.

\section{Literature Review}

In primeval eons, bacterial fermentation had been the avocation of assiduous deliberation regarding rampant perspective, in addition to the conformation of their lysine production response as being documented in conventional literature. Under mentioned literature review will subsidize towards a glance of attempt made around the universe in the discipline of microbiology and fermentation biotechnology:

Ezemba et al., 2016 manifested the assembly of lysine by Microbacterium lacticum via immersed cultivation by many hydro-carbons, sweeten plus nitrogen cradles. Consequence for variable deliberation of carbons plus nitrogen cradles onto the L-lysine growth revealed that $4 \% \mathrm{D}$-glucose and $1 \%$ ammonium sulfate correspondingly improved L-lysine assembly.

Ekwealor and Obeta, 2005 evinced the lysine assembly through Bacillus megaterium. Toting of $0.01 \mathrm{unit} / \mathrm{mL}$ penicillin in the direction of the fermentative agent, instantaneously when inoculated, enthused escalation plus substantially improved lysine accretion. 
Husssain et al., 2015 worked on the optimized cultivation media intended for L-lysine assembly using Corynebacterium glutamicum. Glucose was considered as the finest cradle of carbon along with ammonium sulfate as superlative nitrogen cradle was then improved.

Irshad et al., 2015 evaluated the bulk assembly plus retrieval of lysine using bacterial cultivation via Brevibacterium flavum. Soft creamy clean quartzes of lysine (25g) achieved using $95 \%$ ethanol. Great attentiveness of L-lysine as quartzes formed having $62.5 \%$ pureness plus strenuous cultivated chowder having $8 \%$ L-lysine could be securely expended in rooster consignments in the form of a cradle for Llysine.

Nasab et al., 2007 described the fermentative assembly of L-lysine by $C$. glutamicum using various carbon sources. Outcomes of fermentative trials displayed that the supreme production resembled to treacle is $48 \mathrm{~g} / \mathrm{L}$ with the inoculation time of 96hours.

Rastegari et al., 2013 worked on the enhancement in the assembly of lysine through above-countenance of Asparto-kinase within C. glutamicum. The fallouts of L-lysine test as given by Chin-nard technique indicated that L-lysine fabrication improved almost double paralleled with the parental type, which end up as amplified replica figures like $/ y s-C$ genetic factor in the mutant species.

Reza et al., 2017 revealed the widespread valuation of the lysine assembly method using cultivation of sugar-cane treacle. The finest lodge plan displays full produce return $(0.31 \mathrm{~g}$ lysine g-1 D-glucose) plus yield $(1.99 \mathrm{gL}-1 \mathrm{~h}-1)$, attaining $26.5 \%$ gain proceeding asset having a reimbursement time of $3.8 y e a r s$, lessening aquatic plus vigor ingestion, as well as having a little possible ecological influence (PEI) directory.

Theodora and Bustard, 2005 deliberated the fermentative assembly of lysine via Corynebacterium glutamicum using trans-membrane passage plus metabolic fluidity investigation. Digested fluidity investigation, which remains reflected to stay an actual influential instrument giving treasured evidence about holdups around the assembly of required digesters, is too enclosed as a relative to L-lysine exudation in combination through the importance of conveyance instruments.

Xafenias et al., 2017 described the improvement of an-aerobic L-lysine assembly under Corynebacterium glutamicum electro-fermentations. Current report shows for the 1st time that cathode conductor situations joint through carbon dioxide plus AQ2s acting as a red-ox facilitator could ominously increase equally the produces as well as the piles of L-lysine assembly by $C$. glutamicum.

\section{Introduction}

Amino acids are synthesized through microorganisms from the last 50 years. The most extensive formed amino acid (roughly 900,000 tons each year) occurs as L-glutamic acid, trailed by L-lysine $(420,000$ tons each year) as well as DL-methionine (350,000 tons each year) whiles the rest of the amino acids trail behind (Tryfona and Bustard, 2005). L-lysine is considered as the chief restraining amino acid that every 
single known cereal morsel has, therefore it takes a greater aptitude for increasing the protein content of cereal-based foods mostly around developing countries due to their huge reliance on cereal crops. It is also used for production of antibodies, enzymes and hormones inside the human body as well synthesis of antihypertensive agents and neutralizer for analgesic (Sadoul et al., 2008). Amino acid produced via fermentation has currently touched in a phase where it is frolicking an indispensible part for the cradle of usual amino acids at several manufacturing levels.

Micro-organisms that are already stated to produce L-lysine contain, 'Bacillus megaterium (Ekwealor \& Obeta, 2005), Brevibacterium linens, Streptomyces albulus IFO (Shih et al., 2006), Brevibacterium flavum, M. methylophilis (Ishikawa et al., 2008), B. lactofermentum (Tosaka et al., 1979), B. subtilis and Bacillus laterosporus (Umerie et al., 2000'). As per nitrogen cradles, numerous inorganics plus organic salts as well as compounds like ammonium salts along with other parallel compounds, urea, pure proteolytic organic affluences like peptone plus casein hydrolysate plus yeast extract plus corn steep liquor plus soybean protein hydrolysate, plus numerous other extricates of vegetal as well as animal tissues may possibly be used (Nasab et al., 2007). The final outcome is usually staged as a salt like lysine- $\mathrm{HCl}$ (lysine mono-chloridrate) (Junior et al., 2016) Nonetheless; it can similarly be staged as L-lysine liquid articulations or in granulated configuration. The present work is planned to maximize yields of free lysine obtained in a culture broth by using bacterial strain recover from various soil and water samples.

\section{Materials And Methods}

\section{Isolation of bacteria}

Techniques of microbial isolation undergo drastically changed throughout the past 50 years, as of a labor perspective through increasing mechanization, as well as in concern to the technology embroiled, and hence promptness and accuracy. The isolation of bacterial strains was done stepwise as:

Preliminary screening test

Final screening test

Preliminary screening test

Preliminary screening was encompassed to restraint the presence of L-lysine by the amassed bacteria. The test consists of following parameters:

Collection of samples

Isolation medium

Preparation of medium plates

Serial dilution method

Medium for sub-culturing of bacteria 
Streak plate method

Screening medium for L-lysine production

Cultivation

Detection of L-lysine

\section{Collection of samples}

Fifteen different samples were collected from the adjacent areas of Pakistan Council of Scientific and Industrial Research (PCSIR) laboratories complex Lahore during 2016-2017. The sample contains soil, soil with bird feces, soil with sanitary leakage, bird feces, sewage water, and waste water, soil with vegetation, tap water as well as drain water. All the samples were labeled and weighed as $5 \mathrm{~g}$ for soil samples and $5 \mathrm{~mL}$ for water samples in test tubes and petri plates respectively.

\section{Isolation medium}

A modified medium for the isolation of lysine producing bacteria (e.g., Corynebacterium glutamicum) was employed having the composition as described by Nasab et al., (2007). Quantities in solution consumed were: Glucose $5 \mathrm{~g}$, Peptone $2.5 \mathrm{~g}$, Yeast extracts $2.5 \mathrm{~g}, \mathrm{NaCl} 0.6 \mathrm{~g}, \mathrm{MgSO}_{4} .7 \mathrm{H}_{2} \mathrm{O} 0.7 \mathrm{~g}, \mathrm{MnSO}_{4} \cdot \mathrm{H}_{2} \mathrm{O} 0.02 \mathrm{~g}$, $\mathrm{K}_{2} \mathrm{HPO}_{4} 0.2 \mathrm{~g}, \mathrm{KH}_{2} \mathrm{PO}_{4} 0.2 \mathrm{~g}, \mathrm{CaCO}_{3} 2 \mathrm{~g},\left(\mathrm{NH}_{4}\right)_{2} \mathrm{SO}_{4} 3 \mathrm{~g}$, Urea $1.2 \mathrm{~g}$, Agar $3.4 \mathrm{~g}$. All these ingredients were accurately weighed and dissolved with the assistance of steady rate of stirring in $500 \mathrm{~mL}$ Pyrex beaker using distilled water. More distilled water was supplemented to the relevant mixture and the final volume was made to $250 \mathrm{~mL}$. To facilitate the process of dis-solvation of agar, the beaker containing the medium was placed on the hot plate and was supplied with high temperature until the apparent light beige solution was formed. The $\mathrm{pH}$ was adjusted to 7.0 by using conc. $\mathrm{HCl}$ plus pure $\mathrm{NaOH}$ solution. Ultimately, the medium was dispensed in the $500 \mathrm{~mL}$ conical flask and then sterilized at $121^{\circ} \mathrm{C}$ temperature and 15 lb. pressure for 15 minutes.

\section{Preparation of medium plates}

The petri plates inside which medium had to be dispensed were subjected to autoclave for 15 minutes at $121^{\circ} \mathrm{C}$ temperature and $15 \mathrm{lb}$. pressure followed by thorough washing. However, petri plates could also be sterilized by heating them in oven overnight at $180^{\circ} \mathrm{C}$. The $15 \mathrm{~mL}$ of medium was allocated to every petri plate and their lids were positioned on them. Subsequently the plates were preserved with the cling film and were stored in the uncontaminated location at room temperature until consumption. Still, it was recommended to employ the prepared petri plates within the time extent of 2-3 days to attain the correct affirmative consequences.

\section{Serial dilution method}

A serial dilution is basically a chain of sequential dilutions tapped to reduce an intense culture of cells into a more exploitable concentration. Each dilution can reduce the attentiveness of bacteria by an 
identifiable amount. So, by scheming the total dilution ended the entire chain, it is feasible to know how much bacteria you commenced with. $1 \mathrm{~g}$ or $1 \mathrm{~mL}$ of each sample was added to $9 \mathrm{~mL}$ sterile distilled water and a number of six-fold dilutions were prepared in the same diluent. Aliquots $0.1 \mathrm{~mL}$ of $10-6$ diluted sample suspension was added to the agar plates prepared from the isolation medium and distributed evenly over the surface with the aid of sterile glass spreading rod. Following incubation at $37^{\circ} \mathrm{C}$ for 24 hours, those plates which contained the desired bacterial well isolated colonies were selected as the source of culture to be evaluated for the production of L-lysine.

\section{Medium for sub-culturing of bacteria}

Single colonies of the desired bacteria were then cultured on the nutrient agar medium. The medium was prepared with the American Public Health Association (APHA) standards and the ingredients were utilized according to Cruick-Shank et al., (1975). The amount used (g/L) were: (Nutrient broth 8, Agar 15, Distilled water to raise volume up to $1 \mathrm{~L}$ ). $8 \mathrm{~g}$ powdered nutrient broth was accurately weighed and dissolved with the assistance of steady rate of stirring in $1 \mathrm{~L}$ Pyrex beaker using $1 \mathrm{~L}$ distilled water. Eventually, $15 \mathrm{~g}$ agar was supplemented to the relevant mixture and the final volume was made to $1 \mathrm{~L}$. To facilitate the process of dis-solvation of agar, the beaker containing the medium was placed on the hot plate and was supplied with high temperature until the apparent light beige solution was formed. Ultimately, the medium was dispensed in the $1 \mathrm{~L}$ conical flask and was autoclaved for 15 minutes at $121^{\circ} \mathrm{C}$ temperature and $15 \mathrm{lb}$. pressure. Plates were poured as described previously.

\section{Streak plate method}

The streaking is completed using a disinfected tool, like a cotton swab and normally an inoculation loop or needle. The inoculation loop or needle is first sterilized via passing it over a flame. Once the loop is chill, it is immersed into an inoculum like a broth or a petri plate containing the desired bacterial colony. The inoculation loop is subsequently dragged through the surface of culture plate containing agar back and forth wearing a zigzag motion till approximately $30 \%$ of culture plate has been obscured. The loop afterwards is re-sterilized as well as the plate is twisted 90 degrees. Beginning in the earlier streaked sector, the loop is hauled through these two to three stints continuing the zigzag configuration. The procedure is thenceforth repeated once more ensuing cautious to not tad the formerly streaked areas. Each spell the loop gathers rarer and rarer bacteria until it assembles just lone bacterial cells that have ability to grow into a cluster. The plate must show the heaviest progression in the first unit. The second unit will have less progression and a few sequestered colonies, while the ultimate unit will have the minimum amount of progression and many quarantined colonies.

\section{Screening medium for L-lysine production}

For the production of L-lysine, isolation medium with the exception of agar was prepared. All those ingredients were accurately weighed and dissolved to make the final volume up to $250 \mathrm{~mL}$ with distilled water in a $500 \mathrm{~mL}$ Pyrex beaker. The $\mathrm{pH}$ was adjusted to 7.1 by using conc. $\mathrm{HCl}$ plus pure $\mathrm{NaOH}$ solution. Ultimately, $10 \mathrm{~mL}$ of the medium was dispensed in the test tubes and then sterilized at $121^{\circ} \mathrm{C}$ temperature and $15 \mathrm{lb}$. pressure for 15 minutes. 


\section{Cultivation}

Each test tube was inoculated with a loop-full of desired bacteria from each pure culture plate and incubated with shaking in a horizontal shaking water bath at $100 \mathrm{rpm}$ maintained at $37^{\circ} \mathrm{C}$ for 48 and 72 hours respectively.

\section{Detection of L-lysine}

For the detection of L-lysine, paper chromatographic technique of Momose and Takagi (1978) was employed in the culture broth. This was run on a Whatman filter paper No. 1. Sample spots were applied using a sterile capillary tube, then heat-fixed on a chromatogram following a relevant sequence (Figure -I). It was cogitated as the stationary phase. The solvent systems applied included n-butanol: acetic acid: water (1: 2: 4, v/v). It was also contemplated as the mobile phase. Basically, amino acids have no color. So, all of these measures need to be conceded out "blind", plus the results were perceived when a revealing mediator (e.g., ninhydrin) was applied on the subsequent chromatogram. Hence, the spots were visualized by spraying with a solution of $0.5 \%$ ninhydrin in butanol. For each spot, calculated the Rf value ( $R f$ means relative to front) by using the following formula: $\mathrm{Rf}$ value = distance moved by spot / distance moved by solvent front.

\section{Final screening test}

Final screening test comprise of subsequent parameters:

Purification and maintenance of culture

Production medium

Cultivation

Identification of L-lysine

\section{Purification and maintenance of culture}

Organisms flaunting positive L-lysine production by fermentation were further purified by reiterated cultivation plus sub-culturing using streak plate method and maintained at $4^{\circ} \mathrm{C}$ on agar slants prepared by using nutrient agar medium.

\section{Production medium}

The composition and $\mathrm{pH}$ of the production medium was similar to that of the screening medium for lysine production. Aliquots $20 \mathrm{~mL}$ of this solution were decanted in $50 \mathrm{~mL}$ of Erlenmeyer flasks and sterilized by autoclaving for $15 \mathrm{~min}$ at $121^{\circ} \mathrm{C}$ temperature and $15 \mathrm{lb}$. pressure.

\section{Cultivation}

Each flask was inoculated with two loop-full of organism from each slant culture and incubated within a horizontal shaking water bath at $100 \mathrm{rpm}$ maintained at $37^{\circ} \mathrm{C}$ for 24 hours. The cultivation was executed 
for those selected bacteria that revealed ameliorate results in the preliminary screening tests.

\section{Identification of L-lysine}

Ascending Thin Layer Chromatography (TLC) described by Nasab et al., (2007) was used for the detection of L-lysine in the culture broth. Spots on the TLC plate were concocted, following the same pattern of assembling chromatogram for paper chromatographic technique illustrated in the detection of L-lysine during preliminary screening. The solvent systems applied were also conceived as mentioned earlier. When the sample was put on the plate, the respective solvent or solvent amalgam (renowned as the mobile phase) strained up the plate by means of capillary action. Since dissimilar analytes ascend the respective TLC plate at altered rates, separation was achieved. L-Lysine didn't confer a strong positive response with ninhydrin and the color of spots emerged when heated at $60^{\circ} \mathrm{C}$ on a hot plate. For each spot appear, reckoned the Rf value by means of the formula.

\section{Naming of bacteria}

Naming of PCSIR-NL-42 was primarily based on the taxonomic comparison. The characteristic morphological, cultural, bio-chemical, physiological and chemical properties were taken into consideration (Bergy's manual of Systematic Bacteriology - Vol. 2 1986; Bergy's manual of determinative Bacteriology, 9th Ed. 1994; Goodfellow and Schaal, 1979).

\section{Escalation of L-lysine production}

In comparison, escalation means trying to accomplish the highest or supreme result or outcome deprived of the regard to cost and expenditure. Different parameters studied for escalation included different substrate ranges, different temperature ranges, different metal ions concentration $(\mathrm{mM})$, different $\mathrm{pH}$ ranges, different incubation periods and different inoculum sizes.

\section{Results}

Production and escalation of L-lysine via bacterial fermentation utilizing Streptococcus sp. were conceded in Food and Biotechnology Research Centre (FBRC), Lahore. The rampant investigation was consummate and deliberated scrupulously.

\section{Isolation of Bacterial Strains}

For the isolation of bacteria fifteen different samples were collected from the adjacent areas of Pakistan Council of Scientific and Industrial Research (PCSIR) laboratories complex Lahore. A modified medium was employed having the composition as described by Nasab et al., (2007). In total, twenty-nine (29) bacterial strains were seperated and tested for the accumulation of L-lysine (Table - I). The screening test for L-lysine producing bacterial strains was carried out with the media containing carbohydrate and nitrogen source as chief ingredients supplemented with inorganic salts. 
For the detection of L-lysine, paper chromatographic technique of Momose and Takagi (1978) was employed in the culture broth. The solvent systems applied included n-butanol: acetic acid: water (1: 2: 4, $\mathrm{v} / \mathrm{v})$. The spots were visualized by spraying with a solution of $0.5 \%$ ninhydrin in butanol. The intensity of spots designated as high $(+++)$, medium $(++)$, and low $(+)$ which ultimately indicated the formation of Llysine by each isolate.

The strains showing positive results were then subjected to purification into the same medium to evaluate their L-lysine producing capability and to identify the desired bacteria. Organisms were cultivated in Erlenmeyer flask containing screening medium at $37^{\circ} \mathrm{C}$ for 24 hours in a horizontal shaking water bath at $100 \mathrm{rpm}$.

The qualitative estimation of L-lysine and any other amino acid so produced was checked by ascending Thin Layer Chromatography (TLC) described by Nasab et al., (2007). Rf values were measured and compared with that of authentic amino acids. Table - II shows the Rf values obtained from the authentic amino acids.

The quantitative estimation of L-lysine produces by selected strains was governed by a reliable method as mentioned by Shakori, et al., 2012. Table - III shows the results of the quantitative estimation of Llysine by designated bacterial strains.

\section{Naming of bacterial strains}

The most significant task of bacteriology was to identify the pathogens commencing the clinical sample so that apposite treatment can be established. There are several procedures to identify the altered type of bacteria. Results of taxonomic comparison, i.e., characteristic morphological, cultural, biochemical and physical properties of the selected strains are given in Table -IV.

\section{Escalation of L-lysine production from Streptococcus sp.}

Effect of different substrates on L-lysine production was revealed in Table -V while their relationship in terms of lysine concentration to substrate ranges were prearranged in Figure -II. The ardent stimulatory effect on lysine production was reached using molasses media with vitamins (w) i.e., $24.4 \mathrm{~g} / \mathrm{L}$.

Influence of different temperatures on L-lysine production was mentioned in Table -VI while their relationship in terms of lysine concentration to temperature ranges were given in Figure - III. The potent stimulatory effect on lysine production was achieved at $40^{\circ} \mathrm{C}$ i.e., $24.4 \mathrm{~g} / \mathrm{L}$.

Upshot of different metal ions on L-lysine production was declared in Table -VII while their relationship in terms of lysine concentration to metal ions concentration was assumed in Figure - IV. The powerful stimulatory effect on lysine production was succeeded by adding $1 \mathrm{mM}$ solution of $\mathrm{Mg}$ i.e., $20.4 \mathrm{~g} / \mathrm{L}$.

Consequence of different $\mathrm{pH}$ ranges on L-lysine production was avowed in Table -VIII while their relationship in terms of lysine concentration to various $\mathrm{pH}$ ranges was snapped in Figure $-\mathrm{V}$. The most 
ardent stimulatory effect on lysine production was comprehended at pH 6.5 i.e., $6 \mathrm{~g} / \mathrm{L}$.

Outcome of different incubation periods on L-lysine production was said in Table -IX while their relationship in terms of lysine concentration to incubation periods was specified in Figure - VI. The intense stimulatory effect on lysine production was succeeded after 96 hours i.e., $24.4 \mathrm{~g} / \mathrm{L}$.

Result of different inoculum sizes on L-lysine production was revealed in Table $-X$ while their relationship in terms of lysine concentration to inoculum sizes was accorded in Figure -VII. The fiercest stimulatory effect on lysine production was attained using $0.3 \mathrm{~mL}$ of inoculum i.e., $9.2 \mathrm{~g} / \mathrm{L}$.

Laboratory scale production of L-lysine was carried out using $1 \mathrm{~L}$ Erlenmeyer flask. Optimized conditions for each bacterium were maintained correspondingly. For Streptococcus $s p$. the parameters for optimization i.e., suitable substrate: $(\mathrm{w})$ molasses media with vitamins- optimum temperature: $40^{\circ} \mathrm{C}$ metal ion: Mg-optimum pH: 6.5- incubation period: 96 hours- inoculum size: $0.3 \mathrm{ml} / \mathrm{L}$ results in $23.4 \mathrm{~g} / \mathrm{L}$ of lysine.

\section{Discussion}

The L-lysine production by fermentation was first reported by Casida and Beldwin in 1956, using a twostep method. In the first step, di-amino-pimelic acid (DAP) was accumulated in the medium containing glycerol and corn steep liquor by a lysine requiring strain of Escherichia coli. Conversion of DAP to lysine was then accomplished with DAP-decarboxylase of Aerobacter aerogens. Subsequently, amino acid production by microorganisms continued to attract the attention of various workers throughout the world.

In the present study, the sewage and soil samples collected from different areas of Pakistan Council of Scientific and Industrial Research (PCSIR) laboratories complex Lahore indicated potential for the lysine producing bacteria. In total, twenty-nine (29) bacterial strains were separated and tested for the accumulation of L-lysine: $96.6 \%$ of total isolates. The soil samples were observed more potential than the sewage samples. The screening technique adapted in the present study was that described by Nasab et al., (2007) with slight modification in the composition of screening medium. The cultivation and purification of all isolates on a maintenance or storage medium was carried out as it was certainly justified in the preliminary stage because their potential to synthesize the amino acid was determined.

For the detection of L-lysine, paper chromatographic technique of Momose and Takagi (1978) was employed in the culture broth. The solvent systems applied included n-butanol: acetic acid: water (1: 2: 4, $\mathrm{v} / \mathrm{v})$. The spots were visualized by spraying with a solution of $0.5 \%$ ninhydrin in butanol. Results given in Table-l indicate the formation of L-lysine by each isolate which is according to the intensity of spots. Out of twenty-nine (29) strains, three (3) were found to produce high $(+++)$, ten (10) as medium $(++)$ and sixteen (16) as low (+) intensity producing L-lysine intensively.

The high intensity strains showing positive results were then subjected to purification into the same medium to evaluate their L-lysine producing capability and to identify the desired bacteria. Organisms 
were cultivated in Erlenmeyer flask containing screening medium at $37^{\circ} \mathrm{C}$ for 24 hours in a horizontal shaking water bath at $100 \mathrm{rpm}$. The qualitative estimation of L-lysine and any other amino acid so produced was checked by ascending Thin Layer Chromatography (TLC) described by Nasab et al., (2007). The broth of each cultivated strain was applied on aluminium T.L.C. plates, $0.2 \mathrm{~mm}$ thick and up flow was made at $25^{\circ} \mathrm{C}$. Since the free amino acids have been reported as marked hydrophilic compounds, the separation efficiency was noted with solvent systems, chloroform - methanol - $17 \%$ ammonium hydroxide (2:2:1 v/v), n-butanol - acetic acid - water (4:1:1 v/v) and Phenol - water (3:1 v/v) (Brenner et al., 1969). However, in the present study, the solvent system n-butanol - acetic acid - water (1: 2: $4, v / v)$ provided best separation and was thus used throughout the whole study.

Apart from L-lysine, different amino acid like L-glutamic acid was also identified. $\mathrm{Rf}$ values were measured and compared with that of authentic amino acids. Table - II shows the Rf values obtained from the authentic amino acids. The quantitative estimation of L-lysine produces by selected strains was governed by a reliable method as mentioned by Shakori, et al., 2012. Table - III shows the results of the quantitative estimation of L-lysine by designated bacterial strains.

A morphological screening test which was comprised of Gram's staining, pleomorphism, and capsule staining was first carried out. Strains identified as Gram-positive were then subjected to detailed morphological, cultural, bio-chemical and physiological studies. Results of taxonomic comparison, i.e., characteristic morphological, cultural, biochemical and physical properties of the selected strains are given in Table -IV.

The process intensification (especially, the media composition, addition of certain growth factors and cultural conditions) is indispensible for the scale up and commercial production of amino acids. Jyothi et al., 2005 studies the characterization of glutamic-acid assembly commencing cassava arrowroot plant remains by Brevibacterium divaricatum. By using $0.7 \%$ ammonium-nitrate inside the mixture, maximum glutamate returns of $3.86 \%$, grounded upon the mass of the remains stayed, attained at $38^{\circ} \mathrm{C}$ with a pH as 7.0. Also, maximum glutamate production remained chronicled using $5 \%$ inoculum mass with shakeup speed as $180 \mathrm{rpm}$. According to the present study, effect of different substrates (Table -V \& Figure - II) on lysine production is reached using molasses media with vitamins (w) i.e. $24.4 \mathrm{~g} / \mathrm{L}$. Influence of different temperatures (Table - VI \& Figure - III) is achieved at $40^{\circ} \mathrm{C}$ i.e. $24.4 \mathrm{~g} / \mathrm{L}$. Upshot of different metal ions (Table -VII \& Figure -IV) is succeeded by adding $1 \mathrm{mM}$ solution of Mg i.e. $20.4 \mathrm{~g} / \mathrm{L}$. Consequence of different $\mathrm{pH}$ ranges (Table $-\mathrm{VIII} \&$ Figure $-\mathrm{V}$ ) is comprehended at pH 6.5 i.e. $6 \mathrm{~g} / \mathrm{L}$. Outcome of different incubation periods (Table $-I X \&$ Figure $-\mathrm{VI}$ ) is succeeded after 96 hours i.e. 24.4 $\mathrm{g} / \mathrm{L}$. Result of different inoculum sizes (Table $-X$ \& Figure $-\mathrm{VII}$ ) is attained using $0.3 \mathrm{~mL}$ of inoculum i.e. $9.2 \mathrm{~g} / \mathrm{L}$. Similarly, Ezemba et al., 2016 manifests the assembly of lysine by Microbacterium lacticum via immersed cultivation by many hydro-carbons, sweeten plus nitrogen cradles. Improving the fermented circumstances for $M$. lacticum under immersed media offered a met return as $2.99 \mathrm{mg} / \mathrm{mL}$ of L-lysine within the liquid fermentation following 96 hours. 
From the results of the laboratory scale study, conclusion can be drawn that locally available cane molasses is a useful carbon source along with commercially available glucose. The quantity of L-lysine produced by such bacteria as well as the end products was quite comparable. Thus, keeping in view, the high cost of other carbon sources, commercially available glucose justified its use as a carbon source for L-lysine fermentation. Hence, a considerably less expensive L-lysine fermentation could be carried out using these raw materials.

\section{Declarations}

Ethics approval and consent to participate: not applicable

Consent for publication: not applicable

Availability of data and materials: not applicable

Competing interests: not applicable

Funding: not applicable

Author's contribution: SS did the main work for this research, MS helped in collecting of samples, ZH worked in applying stats to the results, NM helped in making graphs, ZR helped in compiling the information, SA helped in performing the identification.

\section{ACKNOWLEDGEMENT}

I would like to thank Almighty ALLAH for giving me the hope, courage and opportunity to learn and work on this research. Indeed, without His help nothing could be accomplished. I am so grateful to Dr. Rana Abrar Hussain for providing me with excellent and valuable supervision, suggestions, guidance, critics and intellectual advice throughout my research work. I would like to thank from the core of my heart to the research officers and associates in Pakistan Council of Scientific and Industrial Research (PCSIR) Laboratories Complex, Lahore. I got to learn a lot in the kind assistance of them. With pleasure, I acknowledge the debt of affection and love to my parents and siblings for their kind and never-ending assistance in this piece of research work. I completely obliged to our parents for their great support. It was difficult to complete this research work without their financial support and moral assistance.

\section{References}

1. Bergey's Manual of Determinative Bacteriology. (1994). Eds John G. Holt et al., 9 th ed. The Williams and Wilkins, Baltimore, P. 565.

2. Bergey's Manual of Systematic Bacteriology. (1986). Ed. Sneath, P.H.A. vol. 2. Williams and Wilkins, Baltimore, $P .1261$. 
3. Brenner, M., A. Niedewieser, and G. Pataki. (1969). Amino acids and derivatives, In Thin Layer Chromatography. Ed. Stahl, E. 2nd ed. Springer-Verlag. Berlin, P. 730.

4. Casida, L.E. and N.Y. Baldwin. (1956). Preparation of diaminopimelic acid and lysine. U.S. Patent $2,771,369$.

5. Ekwealor, I. A., and J. A. N. Obeta. (2005). Studies on lysine production by Bacillus megaterium. African J. Biotech. 7 (4): 633-638.

6. Ezemba, C.C., C.A. Ozokpo, V.N. Anakwenze, G.C. Anaukwu, C.M.Ogbukagu, C.C. Ekwealor, and I.A. Ekwealor. (2016) Lysine Production of Microbacterium lacticum by Submerged Fermentation Using Various Hydrocarbon, Sugar and Nitrogen Sources. Advances in Microbiology, 6, 797-810.

7. Goodfellow, M. and K.P. Schaal. (1979). Identification method for Norcodia, Actinomadura, and Rhodococcus. In identification methods for microbiologists, 2nd ed, Eds, Skinner, F.A. and Lovelock, D.W. the Society for Applied Bacteriology Technical Series No. 14 Academic Press London p. 261.

8. Hussain, A., Mukhtar, H. and Ikram-ul-haq. (2015). Optimization of fermentation medium for L-lysine production by Corynebacterium glutamicum. Pak. J. Bot., 47(SI): 345-349.

9. Ishikawa, K., Y.T. Murakoshi, F. Ohnishi, K. Kondo, T. Osumi and K. Asano. (2008). Medium composition suitable for L-lysine production by Methylophilus methylotrophusin fed-batch cultivation. J. Biosci. \& Bioengin., 106 (6): 574-579.

10. Irshad, S., Faisal, M., Hashmi, A. S., Javed, M. M., Baber, M. E., Awan, A. R. and Anjum, A. A. (2015). Mass production and recovery of L-lysine by microbial fermentation by Brevibacterium flavum. The Journal of Animal \& Plant Sciences, 25(1): 290-294 ISSN: 1018-7081.

11. Junior, L. A. L., G. V. M. Letti and C. R. Soccol. (2016). Development of an L-Lysine enriched bran for animal nutrition via submerged fermentation by Corynebacterium glutamicum using agroindustrial substrates. Braz. Arch. Biol. Technol. 59: 16150519.

12. Jyothi, A.N., K. Sasikiran, B. Nambisan and C. Balagopalan. (2005). Optimisation of glutamic acid production from cassava starch factory residues using Brevibacterium divaricatum. Process Biochemistry, 40: 3576-3579.

13. Momose, H. and T. Takagi. (1978). Glutamic Acid Production in Biotin-rich Media by Temperaturesensitive Mutants of Brevibacterium lactofermentum, a Novel Fermentation Processt. Agric. Bioi. Chem., 42 (10), 1911 1917.

14. Nasab, M. S. Ansari, and Z. Montazer. (2007). Fermentative Production of Lysine by Corynebacterium glutamicum from Different Carbon Sources. Iran Agricultural Research, 25 (2) and 26 (1-2).

15. Reza, O.A. and Arenas, T.L. (2017). Comprehensive assessment of the L-lysine production process from fermentation of sugarcane molasses. Bioprocess Biosyst Eng.

16. Rastegari, H., Mohsen, C., Azim, A., Sara, C., Zahra, S., Mohammad, R.M., Ali, F. and Soheil, G. (2013). Improvement in the Production of L-Lysine by Over-expression of Aspartokinase (ASK) in $C$. glutamicum ATCC 21799. Tropical Journal of Pharmaceutical Research, 12 (1): 51-56.

17. Sadoul, K., C. Boyault, M. Pabion and S. Khochbin. (2008). Regulation of protein turnover by acetyltransferases and deacetylases. Biochimie, 90: 306-12. 
18. Shih, I. L. and M. H. Shen. (2006). Optimization of cell growth and poly (L-lysine) production in batch and fed-batch cultures by Streptomyces albulus IFO 14147. Process Biochem., 41: 1644-1649.

19. Shakoori, F.R., A.M. Butt, N.M. Ali, M.T. Zahid, A. Rehman and A.R. Shakoori. (2012). Optimization of Fermentation Media for Enhanced Amino Acids Production by Bacteria Isolated from Natural Sources. Pakistan J. Zool., 44(4): 1145-1157.

20. Tosaka, O., H. Morioka, H. Hirakawa, K. Ishii, K. Kubota and Y. Hirose. (1979). US Patent No.4066501.

21. Tryfona, T. and M. T. Bustard. (2005). Fermentative production of lysine by Corynebacterium glutamicum: transmembrane transport and metabolic flux analysis. Process Biochemistry, 40: 499508.

22. Theodora, T. and Bustard, M.T. (2005). Fermentative production of lysine by Corynebacterium glutamicum: trans-membrane transport and metabolic flux analysis Process Biochemistry, 40: 499508. Umerie, S. C., I.A. Ekleawor and I. O. Nwagbo. (2000). Lysine production by Bacillus laterosporus from various carbohydrates and seed meals. Bioresource Technol., 75: 249-252.

23. Xafenias, N., Kmezik, C. and Mapelli, V. (2017). Enhancement of anaerobic lysine production in Corynebacterium glutamicum electrofermentations. Bioelectrochemistry. 117: 40-47.

\section{Tables}

\section{TABLE - I: SCREENING OF BACTERIAL STRAINS AS L-LYSINE PRODUCERS.}


No.

No.

SPOTS

RECORDED

\begin{tabular}{|c|c|c|c|c|}
\hline 1. & 37 & soil with vegetation & 1 & +++ \\
\hline 2. & 38 & soil with bird faeces & 2 & + \\
\hline 3. & 39 & Soil & 1 & + \\
\hline 4. & 40 & bird faeces & 3 & + \\
\hline 5. & 41 & drain water & 5 & + \\
\hline 6. & 42 & soil with bird faeces & 7 & +++ \\
\hline 7. & 43 & sewage water & 6 & ++ \\
\hline 8. & 44 & waste water & 6 & ++ \\
\hline 9. & 45 & soil with sanitary leakage & 5 & +++ \\
\hline 10. & 46 & waste water & 2 & + \\
\hline 11. & 47 & drain water & 4 & + \\
\hline 12. & 48 & sewage water & 8 & + \\
\hline 13. & 49 & Soil & 11 & ++ \\
\hline 14. & 50 & soil with vegetation & 8 & + \\
\hline 15. & 51 & drain water & 3 & ++ \\
\hline 16. & 52 & waste water & 12 & + \\
\hline 17. & 53 & bird feces & 10 & + \\
\hline 18. & 54 & soil with sanitary leakage & 4 & ++ \\
\hline 19. & 55 & soil with vegetation & 11 & + \\
\hline 20. & 56 & sewage water & 7 & + \\
\hline 21. & 57 & Soil & 9 & + \\
\hline 22. & 58 & bird faeces & 10 & ++ \\
\hline 23. & 59 & drain water & 14 & ++ \\
\hline 24. & 60 & waste water & 12 & + \\
\hline 25. & 61 & sewage water & 9 & ++ \\
\hline 26. & 62 & soil with vegetation & 13 & ++ \\
\hline
\end{tabular}




\begin{tabular}{lllll}
27. & 63 & tap water & 15 & + \\
\hline 28. & 64 & soil with sanitary leakage & 14 & ++ \\
\hline 29. & 65 & sewage water & 13 & +
\end{tabular}

(PCSIR-NL-No.) - Pakistan Council of Scientific and Industrial Research (PCSIR)

laboratories complex Lahore-54000, Pakistan.

$(+++)$ - High L-lysine producing strains.

$(++)$ - Medium L-lysine producing strains.

(+) - Low L-lysine producing strains.

\section{TABLE - II: Rf VALUES OF THE STANDARD AMINO ACIDS.}

SERIAL AMINO ACIDS ABBREVIATIONS Rf VALUES

No.

$\begin{array}{llll}\text { 1. } & \text { Lysine } & \text { Lys } & 0.14 \\ \text { 2. } & \text { Glutamic acid } & \text { Glu } & 0.25\end{array}$

Chromatographic plates - Aluminium T.L.C. Plates $(20$ X 20cm).

Solvent system - n-butanol -acetic acid -water (1: 2: 4, v/v).

Solvent migration $-17 \mathrm{~cm}$ at $25^{\circ} \mathrm{C}$

Duration - 8 hours.

By following all the statistical parameters pragmatic on the quantitative estimation for L-lysine production and intensification, it was clinched that the mean value of lysine produce was trailed by various alphabetical letters in same column which remain portentously different at a level of ' $p \leq$ ' according to Duncan's new multiple range test (5\%) using ANOVA, while ' \pm ' indicates standard error calculated from the Microsoft Excel 2016 formula sheet. However, LSD means least significant difference. Significance level, error mean square and degree of freedom were also mentioned accordingly.

\section{TABLE - III: QUANTITATIVE ESTIMATION OF L-LYSINE.}


SERIAL STRAIN

L-LYSINE PRODUCED

No. (PCSIR-NL-No.) (g/L).

\begin{tabular}{llll}
\hline 1. & 37 & $13.3 \pm 1.27 \mathrm{bc}$ & 2.203 \\
\hline 2. & 41 & $10.5 \pm 2.27 \mathrm{bcde}$ & 3.946 \\
\hline 3. & 42 & $20.1 \pm 3.49 \mathrm{a}$ & 6.057 \\
\hline 4. & 43 & $10.4 \pm 5.06 \mathrm{bcde}$ & 8.772 \\
\hline 5. & 44 & $8.1 \pm 2.55 \mathrm{bcde}$ & 4.424 \\
\hline 6. & 45 & $15.4 \pm 0.87 \mathrm{ab}$ & 1.514 \\
\hline 7. & 46 & $12 \pm 3.02 \mathrm{bcd}$ & 5.245 \\
\hline 8. & 47 & $6.7 \pm 2.41 \mathrm{cde}$ & 4.174 \\
\hline 9. & 48 & $7.8 \pm 1.10 \mathrm{cde}$ & 1.908 \\
\hline 10. & 49 & $3.9 \pm 0.43 \mathrm{e}$ & 0.750 \\
\hline 11. & 50 & $3.5 \pm 0.67 \mathrm{e}$ & 1.171 \\
\hline 12. & 51 & $6.8 \pm 1.04 \mathrm{cde}$ & 1.814 \\
\hline 13. & 52 & $5.8 \pm 1.55 \mathrm{de}$ & 2.690 \\
\hline 14. & 53 & $4.3 \pm 0.45 \mathrm{e}$ & 0.793 \\
\hline 15. & 54 & $9.3 \pm 2.18 \mathrm{bcde}$ & 3.780 \\
\hline 16. & 55 & $6.1 \pm 0.35 \mathrm{cde}$ & 0.611 \\
\hline
\end{tabular}

Significance level $=.05$

Error mean square $=14.14$

Degree of freedom $=32$

LSD $.05=6.337$

STANDARD DEVIATION 
Strain Morphological Characteristics

\begin{tabular}{|c|c|c|c|c|c|}
\hline \multirow{3}{*}{$\begin{array}{l}\text { (PCSIR- } \\
\text { NL- } \\
\text { NO.) }\end{array}$} & \multirow{3}{*}{$\begin{array}{l}\text { Gram } \\
\text { Stain }\end{array}$} & \multicolumn{2}{|l|}{ Cell Form } & \multirow[t]{3}{*}{ Pleomorphism } & \multirow{3}{*}{$\begin{array}{l}\text { Capsule } \\
\text { Stain }\end{array}$} \\
\hline & & Young Cultures & Old Cultures & & \\
\hline & & (12 To 24 Hours Old) & $\begin{array}{l}\text { (72 To } 120 \text { Hours } \\
\text { Old) }\end{array}$ & & \\
\hline \multirow[t]{2}{*}{42} & $\begin{array}{l}\text { Positive } \\
(+)\end{array}$ & $\begin{array}{l}\text { Rounded Cocci, } \\
\text { Mostly Single, Some } \\
\text { Occurs in Pairs. }\end{array}$ & $\begin{array}{l}\text { Composed Largely } \\
\text { or Entirely of } \\
\text { Coccoid Cells. }\end{array}$ & + & + \\
\hline & Violet & & & & \\
\hline
\end{tabular}

\begin{tabular}{lllll}
\hline \multicolumn{3}{l}{ Biochemical Characteristics } & & \\
\hline Indole & Methyl & Catalase & Starch & Casein \\
Test & Red & Test & Hydrolysis & Hydrolysis \\
& Test & & Test & Test \\
\hline- & + & - & - & - \\
\hline
\end{tabular}

Cultural Characteristics

Small, Smooth, Entire, Circular, Convex, Pale Yellow in Colour.

Physiological Characteristics

\begin{tabular}{lllll}
\hline $\begin{array}{l}\text { Optimum } \\
\text { Temperature }\end{array}$ & $\begin{array}{l}\text { Oxygen } \\
\text { Requirements }\end{array}$ & Growth & \multicolumn{2}{c}{ Growth in $\mathrm{NaCl}$} \\
\cline { 4 - 5 } & & After & & \\
\hline $27-45^{\circ} \mathrm{C}$ & FA & Heat $\left(80^{\circ} \mathrm{C}\right)$ & & $10 \%$ \\
\hline
\end{tabular}

A -Aerobes; FA -Facultative Anaerobes

\section{TABLE - V: EFFECT OF DIFFERENT SUBSTRATES ON L-LYSINE PRODUCTION BYStreptococcus $s p$.}


SERIAL SUBSTRATE RANGES

L-LYSINE

PRODUCED

$(g / L)$.

1. Glucose media with vitamins (g)

$22.8 \pm 0.02 b$

$10 \pm 0.04 \mathrm{~g}$

$24.4 \pm 0.03 a$

$12 \pm 0.02 f$

$21.2 \pm 0 c$

(B)

6.

Molasses media without vitamins ( $\mathrm{m}$ )

7. Simple glucose media (o)

$7 . \quad$ Simple glu
Significance level $=.05$

Error mean square $=0.001$

Degree of freedom $=7$

LSD $.05=0.07$

5

Molasses media for Bacillus without shaking (b)

Molasses media forBacillus with shaking
STANDARD

DEVIATION

\section{TABLE - VI: EFFECT OF DIFFERENT TEMPERATURES ON L-LYSINE PRODUCTION byStreptococcus sp.}

\begin{tabular}{llll}
$\begin{array}{l}\text { SERIAL } \\
\text { No. }\end{array}$ & TEMPERATURE & $\begin{array}{l}\text { L-LYSINE PRODUCED } \\
\text { RANGES }\end{array}$ & $\begin{array}{l}\text { STANDARD } \\
(\mathbf{g} / \mathrm{L}) .\end{array}$ \\
\hline 1. & $25^{\circ} \mathrm{C}$ & $6.8 \pm 0.01 \mathrm{f}$ & 0.041 \\
\hline 2. & $27^{\circ} \mathrm{C}$ & $16.8 \pm 0.01 \mathrm{C}$ & 0.041 \\
\hline 3. & $30^{\circ} \mathrm{C}$ & $18 \pm 0.02 \mathrm{~b}$ & 0.028 \\
\hline 4. & $35^{\circ} \mathrm{C}$ & $18 \pm 0.03 \mathrm{~b}$ & 0.042 \\
\hline 5. & $37^{\circ} \mathrm{C}$ & $10.4 \pm 0.01 \mathrm{e}$ & 0.014 \\
\hline 6. & $40^{\circ} \mathrm{C}$ & $24.4 \pm 0.02 \mathrm{a}$ & 0.028 \\
\hline 7. & $45^{\circ} \mathrm{C}$ & $11.2 \pm 0.01 \mathrm{~d}$ & 0.014 \\
\hline
\end{tabular}

Significance level $=.05$

Error mean square $=6 \mathrm{E}-04$ 
Degree of freedom $=7$

LSD $.05=0.05$

\section{TABLE - VII: EFFECT OF DIFFERENT METAL IONS ON L-LYSINE PRODUCTION BYStreptococcus $s p$.}

\begin{tabular}{llll}
$\begin{array}{lll}\text { SERIAL } \\
\text { No. }\end{array}$ & $\begin{array}{l}\text { METAL IONS } \\
(\mathrm{mM})\end{array}$ & $\begin{array}{l}\text { L-LYSINE PRODUCED } \\
(\mathrm{g} / \mathrm{L}) .\end{array}$ & $\begin{array}{l}\text { STANDARD } \\
\text { DEVIATION }\end{array}$ \\
\hline 1. & $\mathrm{Ca}$ & $12.4 \pm 0.01 \mathrm{c}$ & 0.014 \\
\hline 2. & $\mathrm{Na}$ & $11.6 \pm 0.02 \mathrm{~d}$ & 0.028 \\
\hline 3. & $\mathrm{~K}$ & $10.8 \pm 0.02 \mathrm{e}$ & 0.028 \\
\hline 4. & $\mathrm{Mn}$ & $9.6 \pm 0.02 \mathrm{f}$ & 0.028 \\
\hline 5. & $\mathrm{Fe}$ & $18 \pm 0.01 \mathrm{~b}$ & 0.014 \\
\hline 6. & $\mathrm{Mg}$ & $20.4 \pm 0.08 \mathrm{a}$ & 0.113 \\
\hline 7. & $\mathrm{Cu}$ & $2.8 \pm 0.01 \mathrm{~g}$ & 0.014 \\
\hline
\end{tabular}

Significance level $=.05$

Error mean square $=0.002$

Degree of freedom $=7$

LSD $.05=0.112$

\section{TABLE - VIII:EFFECT OF DIFFERENT PH RANGES ON L-LYSINE PRODUCTION BYStreptococcus $s p$.}


SERIAL PHRANGES L-LYSINE PRODUCED STANDARD

\begin{tabular}{llll} 
No. & & $(\mathrm{g} / \mathrm{L})$. & DEVIATION \\
\hline 1. & 5.5 & $4 \pm 0.02 \mathrm{~b}$ & 0.028 \\
\hline 2. & 6 & $2.4 \pm 0.03 \mathrm{e}$ & 0.042 \\
\hline 3. & 6.5 & $6 \pm 0.05 \mathrm{a}$ & 0.070 \\
\hline 4. & 7 & $2.8 \pm 0.02 \mathrm{~d}$ & 0.028 \\
\hline 5. & 7.5 & $2.8 \pm 0.01 \mathrm{~d}$ & 0.014 \\
\hline 6. & 8 & $2.4 \pm 0.02 \mathrm{e}$ & 0.028 \\
\hline 7. & 8.5 & $3.2 \pm 0.02 \mathrm{c}$ & 0.028 \\
\hline
\end{tabular}

Significance level $=.05$

Error mean square $=0.001$

Degree of freedom $=7$

LSD .05 $=0.09$

TABLE - IX:EFFECT OF DIFFERENT INCUBATION PERIODS ON LLYSINE PRODUCTION BYStreptococcus sp.

\begin{tabular}{llll}
$\begin{array}{lll}\text { SERIAL } \\
\text { No. }\end{array}$ & $\begin{array}{l}\text { INCUBATION } \\
\text { PERIOD (hours) }\end{array}$ & $\begin{array}{l}\text { L-LYSINE PRODUCED } \\
(\mathrm{g} / \mathrm{L}) .\end{array}$ & $\begin{array}{l}\text { STANDARD } \\
\text { DEVIATION }\end{array}$ \\
\hline 1. & 24 & $4 \pm 0.02 \mathrm{~g}$ & 0.028 \\
\hline 2. & 48 & $2.8 \pm 0.03 \mathrm{i}$ & 0.042 \\
\hline 3. & 72 & $3.2 \pm 0.01 \mathrm{~h}$ & 0.014 \\
\hline 4. & 96 & $24.4 \pm 0.05 \mathrm{a}$ & 0.070 \\
\hline 5. & 120 & $11.2 \pm 0.03 \mathrm{c}$ & 0.042 \\
\hline 6. & 144 & $1.6 \pm 0.07 \mathrm{i}$ & 0.098 \\
\hline 7. & 168 & $7.2 \pm 0.03 \mathrm{f}$ & 0.042 \\
\hline 8. & 192 & $9.2 \pm 0.04 \mathrm{e}$ & 0.056 \\
\hline 9. & 216 & $13.2 \pm 0.06 \mathrm{~b}$ & 0.084 \\
\hline 10. & 240 & $10.8 \pm 0.03 \mathrm{~d}$ & 0.042 \\
\hline
\end{tabular}

Significance level $=.05$ 
Error mean square $=0.02$

Degree of freedom $=10$

LSD $.05=0.351$

\section{TABLE - X:EFFECT OF DIFFERENT INOCULUM SIZES ON L-LYSINE PRODUCTION BYStreptococcus $s p$.}

\begin{tabular}{llll}
$\begin{array}{l}\text { SERIAL } \\
\text { No. }\end{array}$ & $\begin{array}{l}\text { INOCULUM SIZES } \\
(\mathrm{ml} / \mathrm{L})\end{array}$ & $\begin{array}{l}\text { L-LYSINE PRODUCED } \\
(\mathrm{g} / \mathrm{L}) .\end{array}$ & $\begin{array}{l}\text { STANDARD } \\
\text { DEVIATION }\end{array}$ \\
\hline 1. & 0.1 & $6.8 \pm 0.01 \mathrm{c}$ & 0.014 \\
\hline 2. & 0.2 & $7.2 \pm 0.03 \mathrm{~b}$ & 0.042 \\
\hline 3. & 0.3 & $9.2 \pm 0.04 \mathrm{a}$ & 0.056 \\
\hline 4. & 0.4 & $5.2 \pm 0.05 \mathrm{e}$ & 0.070 \\
\hline 5. & 0.5 & $6 \pm 0.06 \mathrm{~d}$ & 0.084 \\
\hline 6. & 0.6 & $4.4 \pm 0.03 \mathrm{~g}$ & 0.042 \\
\hline 7. & 0.7 & $4.8 \pm 0.01 \mathrm{f}$ & 0.014 \\
\hline 8. & 0.8 & $3.2 \pm 0.03 \mathrm{~h}$ & 0.042 \\
\hline 9. & 0.9 & $2.8 \pm 0.02 \mathrm{i}$ & 0.028 \\
\hline 10. & 1 & $1.6 \pm 0.03 \mathrm{j}$ & 0.042 \\
\hline
\end{tabular}

Significance level $=.05$

Error mean square $=0.002$

Degree of freedom $=10$

LSD $.05=0.108$

Figures 


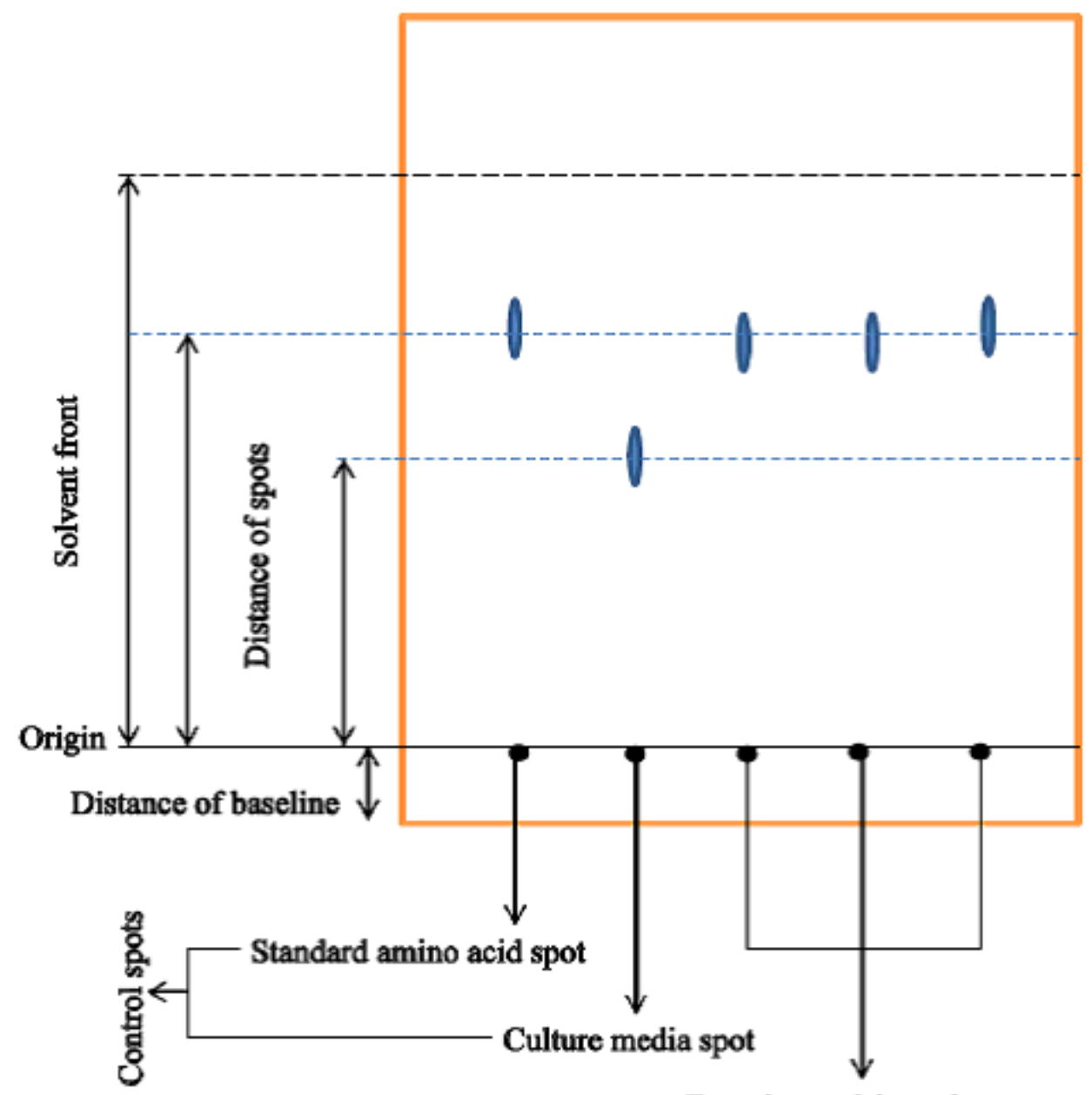

Experimental /sample spots

Figure 1

CHROMATOGRAM / TLC PLATE

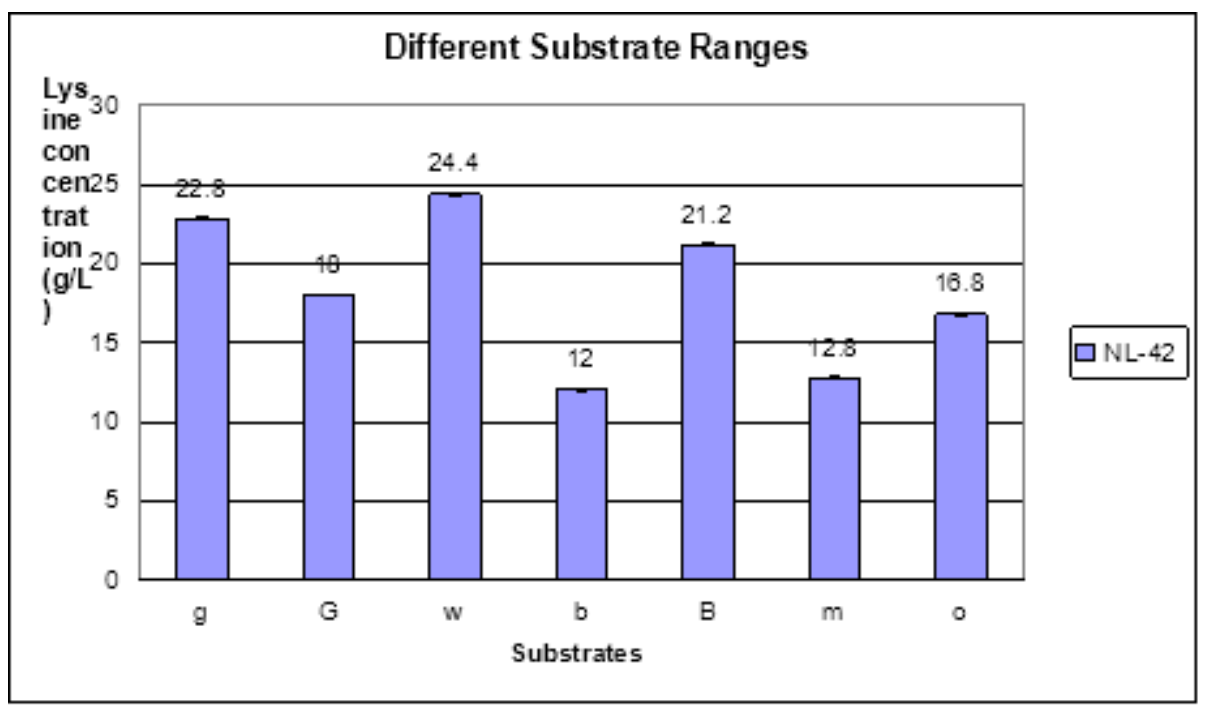

Figure 2 


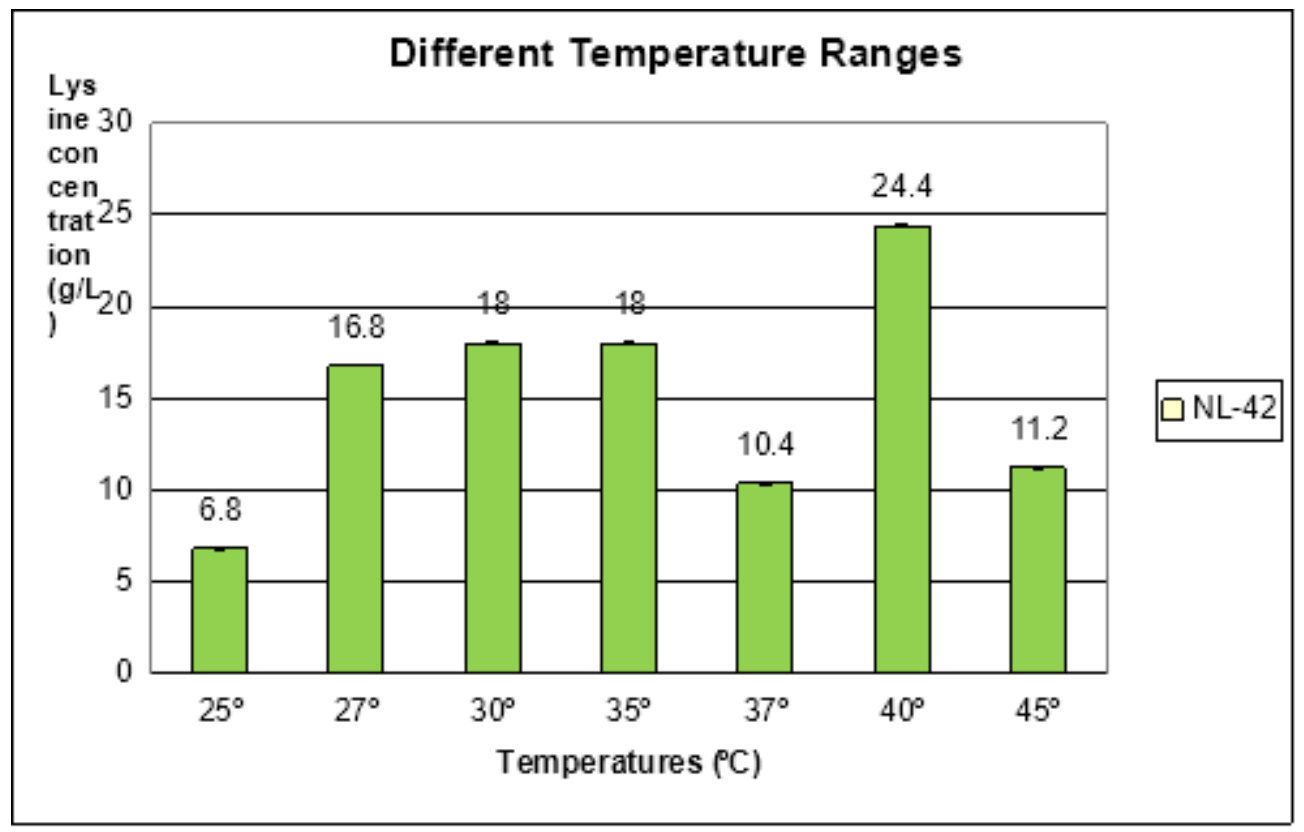

\section{Figure 3}

GRAPHICAL REPRESENTATION OF DIFFERENT TEMPERATURES ON L-LYSINE PRODUCTION BY Streptococcus sp.

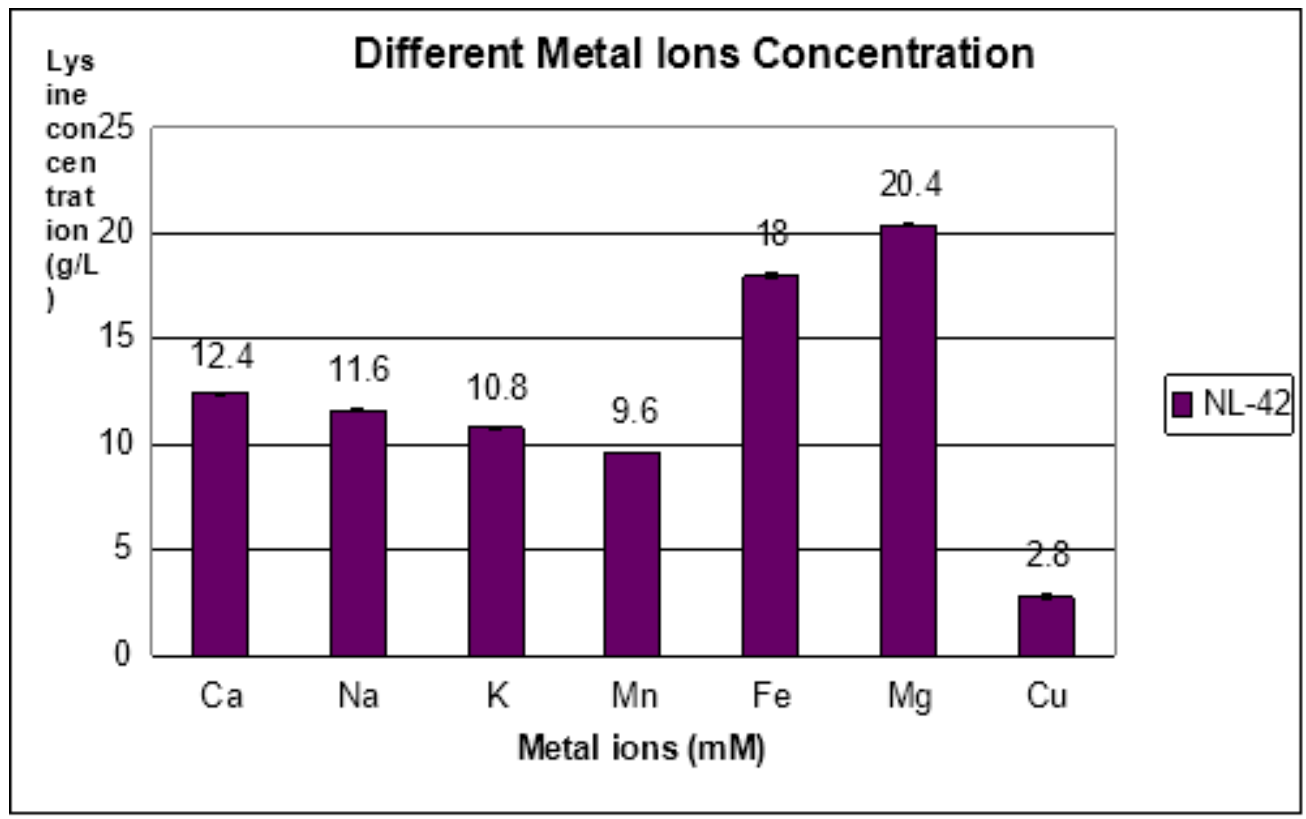

Figure 4

GRAPHICAL REPRESENTATION OF DIFFERENT METAL IONS ON L-LYSINE PRODUCTION BY Streptococcus sp. 


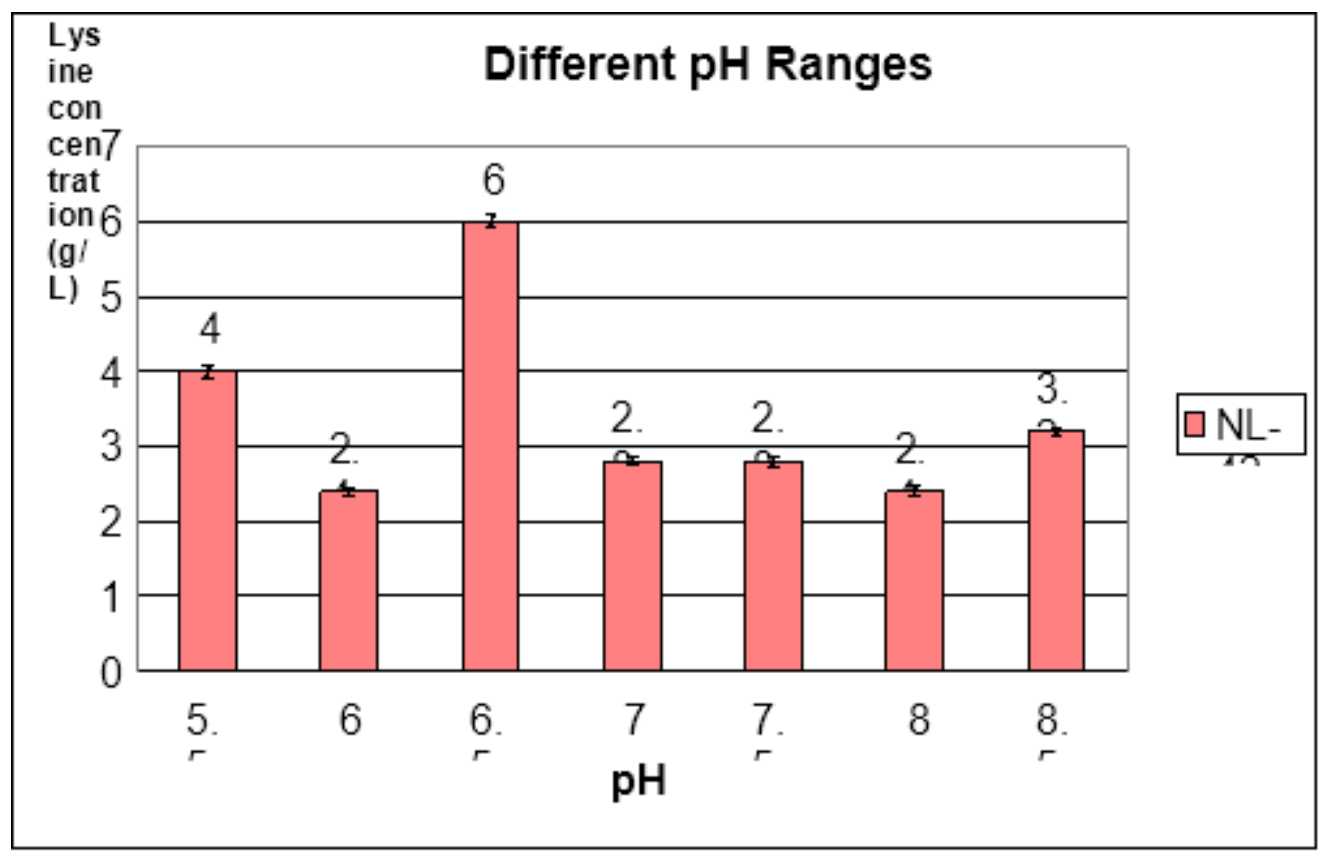

Figure 5

GRAPHICAL REPRESENTATION OF DIFFERENT PH RANGES ON L-LYSINE PRODUCTION BY Streptococcus sp.

\section{Different Incubation Periods}

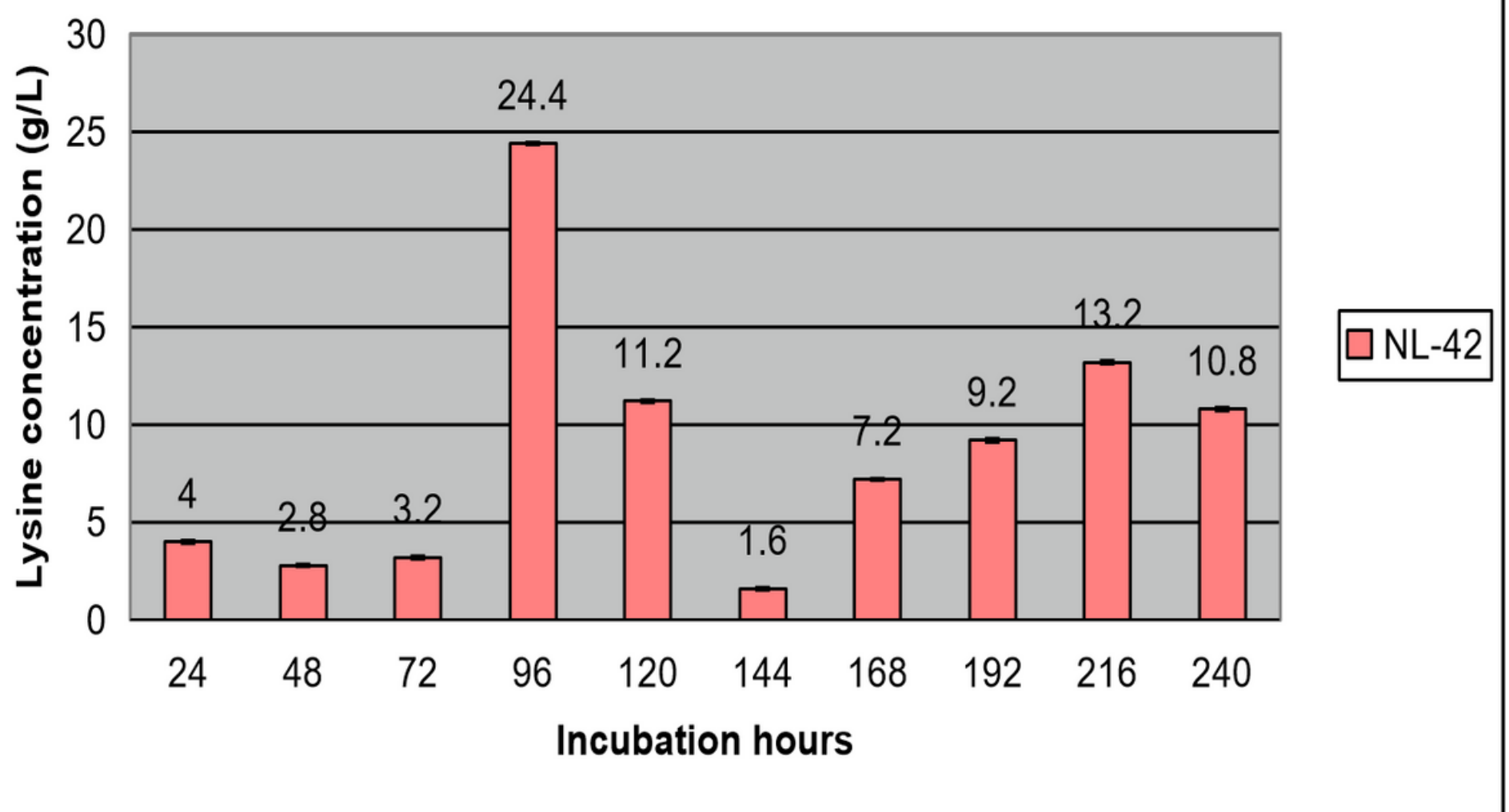

Figure 6 


\section{Different Inoculum Sizes}

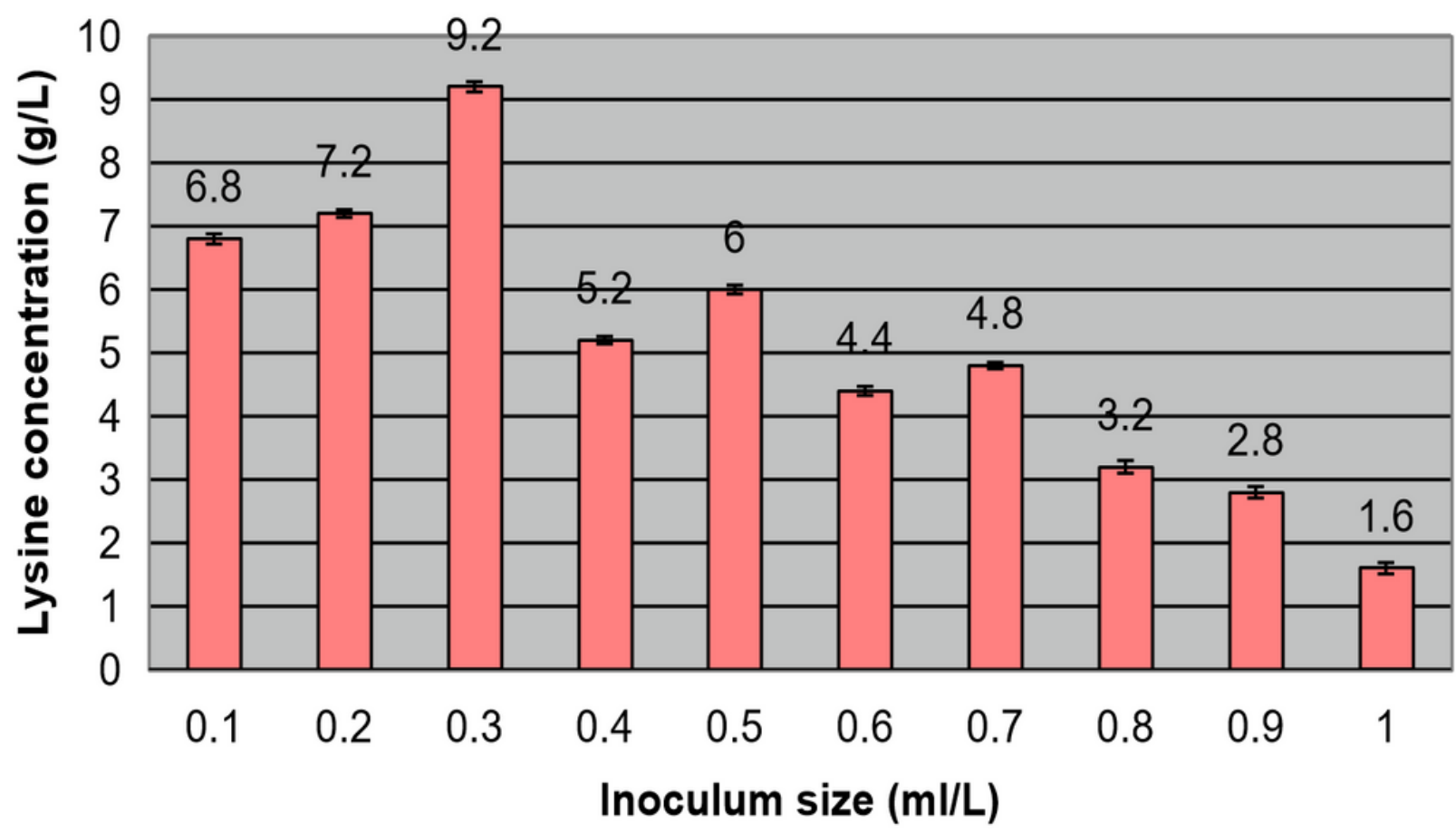

Figure 7

GRAPHICAL REPRESENTATION OF DIFFERENT INOCULUM SIZES ON L-LYSINE PRODUCTION BY Streptococcus sp. 